\title{
RHEUMATIC HEART DISEASE IN THE SUDAN
}

\author{
BY \\ A. M. HALIM AND JOHN E. JACQUES \\ From Khartoum Hospital and the Department of Surgery, University of Khartoum, Sudan
}

Received November 14, 1960

No survey of the pattern of heart disease in the Sudan has hitherto been made. As would be expected, such lesions as syphilitic aortitis and endomyocardial fibrosis (O'Brien, 1954) are seen quite often. Nevertheless, the most striking feature is an extremely high incidence of rheumatic heart disease. There is little doubt that this is unusual in African territories. For example, Arnott (1959), as a result of extensive tours of the continent, concluded that "rheumatic heart disease, as judged by the frequency of mitral stenosis, was relatively rare." Again, in neighbouring Uganda, Williams et al. (1954) found rheumatic lesions in only 7 per cent of 231 autopsies made on patients dying from cardiac causes. A later report from the same country (Shaper and Williams, $1960)$ showed a rather higher incidence $(13 \%)$ among 712 cardiac cases admitted to Mulago Hospital. In this paper we have analysed 958 consecutive cases of heart disease investigated in Khartoum over a three-year period from $1957 ; 243$ of these $(25 \%)$ had rheumatic disease (Table I).

TABLE I

Analysis of 958 Cardiac Cases Investigated in Khartoum During the Years 1957-1960

\begin{tabular}{c|c|c|c|c|c|c|c|c}
\hline $\begin{array}{c}\text { Cardiac } \\
\text { disorders }\end{array}$ & Congenital & $\begin{array}{c}\text { Syphilitic } \\
\text { aortitis }\end{array}$ & $\begin{array}{c}\text { Hyper- } \\
\text { tension }\end{array}$ & $\begin{array}{c}\text { Ischæmic } \\
\text { heart } \\
\text { disease }\end{array}$ & $\begin{array}{c}\text { Pulmonary } \\
\text { heart } \\
\text { disease }\end{array}$ & $\begin{array}{c}\text { Endomyo- } \\
\text { cardial } \\
\text { fibrosis }\end{array}$ & $\begin{array}{c}\text { Rheumatic } \\
\text { heart } \\
\text { disease }\end{array}$ & $\begin{array}{c}\text { Miscel- } \\
\text { laneous }\end{array}$ \\
\hline $\begin{array}{c}\text { Percentage } \\
\text { of total }\end{array}$ & $3 \cdot 7$ & 6.0 & $44 \cdot 4$ & $12 \cdot 6$ & $2 \cdot 0$ & $3 \cdot 2$ & $25 \cdot 4$ & $2 \cdot 7$ \\
\hline
\end{tabular}

An increasingly high proportion of mitral stenosis in the Sudan has been apparent to one of us (A.M.H.) for several years. In 1937, an analysis was made of 100 consecutive cases of heart disease admitted to Khartoum Hospital: 80 had cardiovascular syphilis, and only 3 had mitral stenosis. In a paper read before the Sudan Branch of the British Medical Association, Dr. Dawood Mustafa (1945) described 66 cases of heart disease admitted to Omdurman Hospital in a six-month period. Of these, only nine $(14 \%)$ were rheumatic. Apart from these two isolated studies, no reliable statistics are available up to the beginning of the present survey in 1957, but it would seem that rheumatic heart disease is increasing.

Autopsies are few and far between in a predominantly Muslim community such as this. In fact, it has only been possible to obtain post-mortem confirmation of the lesion in 39 of the 958 cases reviewed here. Diagnosis has been made on clinical, radiographic, and electrocardiographic grounds. In some instances the differential diagnosis between endomyocardial fibrosis and rheumatic mitral regurgitation has been impossible to make with certainty: these amounted to a total of 37 case, and it was decided to exclude them altogether, so they are not among the total of 958 cases reviewed. 
During the last year of the three-year period covered, 20 patients with mitral stenosis have undergone valvotomy. One of these had an aortic valvotomy performed at the same time. The pathological changes in the mitral valves were in all cases similar to those previously encountered by one of us (J.E.J.) in Great Britain. There is therefore no reason to suppose that we are dealing with a different disease. Six of these valves were found to be calcified to a varying degree. In fourteen cases a good split was obtained by finger fracture; in the other six a mechanical dilator was used by the transventricular route (Logan and Turner, 1959). The average age of these patients was 20 years. Three of them had detectable regurgitation; in another, Grade I regurgitation was produced by operation.

\section{Age ANd Sex InCIDENCE}

A notable feature was the early age at which patients presented with symptoms due to chronic rheumatic heart disease (Fig. 1 and Table II). In England the average age is 37 years (Wood,

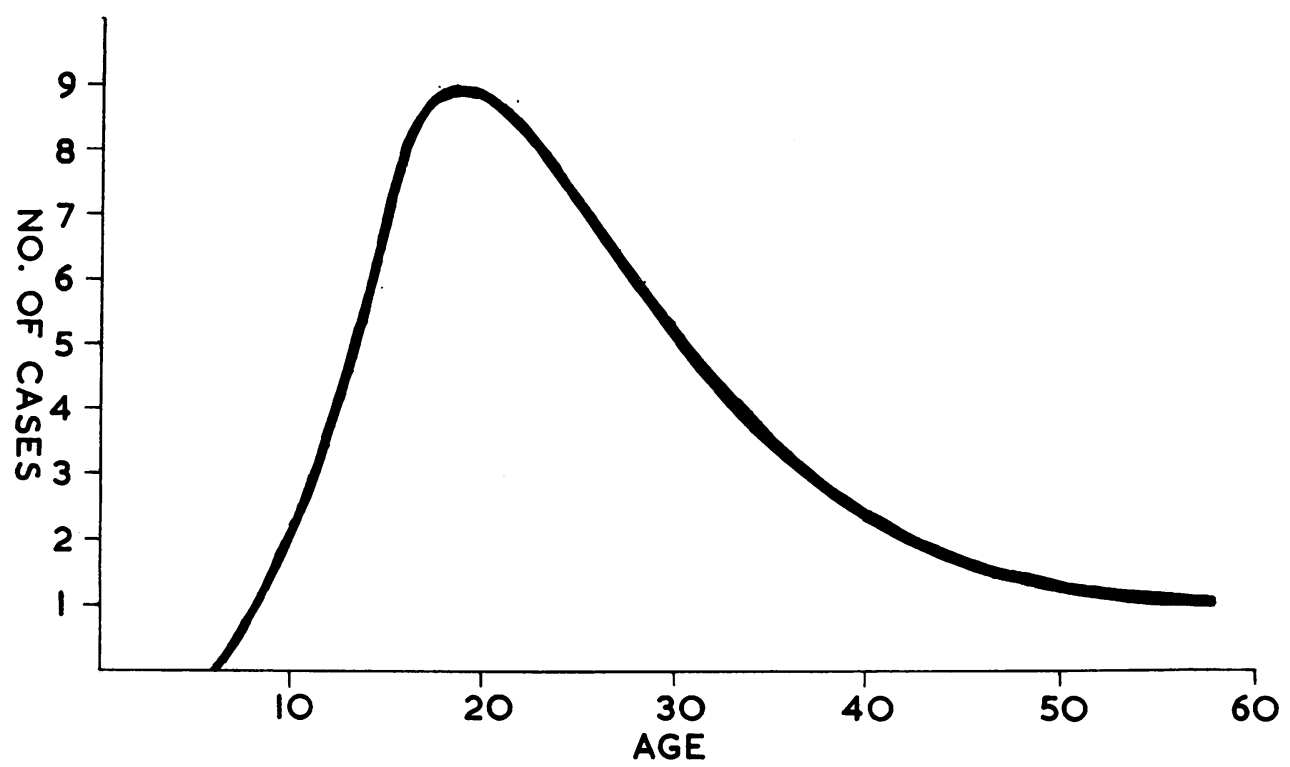

FIG. 1.-Curve showing age distribution among 243 patients with rheumatic heart disease.

1956); in our series it is 27 years. This corresponds closely with the earlier presentation noted in Uganda (Shaper and Williams, 1960) and in Nigeria (Beet, 1956). The progress of the disease is probably even more rapid than these mean ages would suggest. Diagnosis is most probably made at an earlier stage in England, and only two of our cases of mitral stenosis were symptomless.

A history of rheumatic fever could be obtained in 74 per cent of the 243 cases. A further 8 per cent gave a history of recurrent tonsillitis, and 0.9 per cent of repeated epistaxis (Levine, 1945). Frequently, a satisfactory history was not obtainable. A preponderance of our patients $(58 \%)$ were female. This proportion corresponds closely with the sex ratio in America and Europe (White, 1951).

\section{GeOgRaPhical Distribution}

While these patients were drawn from all parts of the Sudan, difficulties in communication made the proportion attending from the extreme Southern Provinces less than would be representative. Nevertheless, in a recent short tour of the provinces of Equatoria and Bahr-ElGhazal many examples of rheumatic heart disease were encountered. One of these, a woman, is 
TABLE II

Age Distribution Among 243 Cases of Rheumatic Heart Disease

\begin{tabular}{lcccc|c|c|c|c|c|c}
\hline Age group &. &.. &.. &.. & $0-9$ & $10-19$ & $20-29$ & $30-39$ & $40-49$ & $50+$ \\
\hline Percentage in each &.. & $\ldots$ & $\ldots$ & $9 \cdot 8$ & $35 \cdot 8$ & 25 & 16 & $11 \cdot 6$ & $1 \cdot 8$ \\
\hline
\end{tabular}

TABLE III

Distribution of Lesions among 243 Patients with Rheumatic Heart Disease

\begin{tabular}{|c|c|c|c|c|c|}
\hline $\begin{array}{l}\text { Valvular } \\
\text { lesion }\end{array}$ & $\begin{array}{c}\text { Mitral } \\
\text { stenosis }\end{array}$ & $\begin{array}{l}\text { Mitral } \\
\text { regurgitation }\end{array}$ & $\begin{array}{c}\text { Mitral } \\
\text { stenosis } \\
+ \\
\text { regurgitation }\end{array}$ & $\begin{array}{c}\text { Aortic } \\
\text { disease } \\
\text { (regurgitation } \\
\text { and/or } \\
\text { stenosis) }\end{array}$ & $\begin{array}{l}\text { Aortic } \\
+ \text { mitral } \\
\text { disease }\end{array}$ \\
\hline Incidence $\ldots \quad \ldots$ & $39 \%$ & $15 \cdot 5 \%$ & $26 \cdot 5 \%$ & $9 \%$ & $10 \%$ \\
\hline
\end{tabular}

included in the survey; she was the only patient so far to reach Khartoum for operation. Only a few patients with what was probably endomyocardial fibrosis were examined, although syphilitic aortitis appeared to be a very common disease. We mention this because these parts of the Sudan adjoin Uganda, where the incidence of rheumatic disease is lower than that of endomyocardial fibrosis (Williams et al., 1954). In Tanganyika, the latter disease is uncommon (Turner and Manson-Bahr, 1960). Yet these three territories have many climatic, racial, dietary, and social characteristics in common.

\section{VALVULAR Lesions}

The distribution of the types of rheumatic lesions is shown in Table III. Mitral stenosis was the commonest lesion $(72.5 \%$ ) and was the sole finding in 39 per cent. It was associated with mitral regurgitation in 26.5 per cent and with aortic valve disease in 7 per cent of cases. Pure aortic disease occurred in 9 per cent. The 15.5 per cent with mitral regurgitation as the predominant lesion all gave an unequivocal history of acute rheumatism. As mentioned above, when differentiation between rheumatic heart disease and left-sided endomyocardial fibrosis could not be made the case was excluded from the series. Bacterial endocarditis was present in 5 per cent. Finally, 13 per cent showed atrial fibrillation.

Apart from this survey, it is known that admissions to Khartoum Hospital for acute rheumatism have increased considerably in the last few years. In these patients the malady appears to be quite typical, with high anti-streptolysin-O titres. We are at present engaged in a follow up study with the aim of determining whether or not the increase in rheumatic heart disease is progressive.

\section{Summary AND CONCLUSIONS}

Of a total of 958 patients with cardiac disorders investigated at Khartoum Hospital over a recent three-year period, $243(25 \%)$, were suffering from rheumatic heart disease. Twenty of these patients have been operated upon, typical valvular lesions being found. The relative incidence was considerably higher than has been reported from other parts of Africa. It appears almost certain that there has been a real increase over the last twenty years.

We would like to thank the Director, Medical Services, Dr. A. A. Zaki, and Professor Julian Taylor, Head of the Department of Surgery, University of Khartoum, for permission to publish. We also thank those physicians at Khartoum Hospital who have co-operated in this survey.

2C 


\section{REFERENCES}

Arnott, W. M. (1959). Brit. med. J., 2, 1273.

Beet, E. A. (1956). Trans. R. Soc. Trop. Med. Hyg., 48, 309.

Levine, S. (1945). Clinical Heart Disease. 3rd ed. Sanders \& Co., London.

Logan, A., Turner, R. (1959). Lancet, $2,874$.

O'Brien, W. (1954). Brit. med. J., $2,899$.

Turner, P., Manson-Bahr, P. E. C. (1960). Brit. Heart J., 22, 305.

Shaper, A. C., Williams, A. W. (1960). Trans. R. Soc. Trop. Med. Hyg., 54, 12.

White, P. D. (1951). Heart Disease. 4th ed. Macmillan \& Co. New York.

Williams, A. W., Ball, J. D., Davies, J. N. P. (1954). Trans. R. Soc. Trop. Med., Hyg., 48, 290. 